\title{
Crafting, Community, and Collaboration: Reflections on the Ethnographic Sala Project at the Pukara Lithic Museum, Peru
}

Elizabeth A. Klarich

Smith College, eklarich@smith.edu

Follow this and additional works at: https://scholarworks.smith.edu/ant_facpubs

Part of the Anthropology Commons

\section{Recommended Citation}

Klarich, Elizabeth A., "Crafting, Community, and Collaboration: Reflections on the Ethnographic Sala Project at the Pukara Lithic Museum, Peru" (2014). Anthropology: Faculty Publications, Smith College, Northampton, MA.

https://scholarworks.smith.edu/ant_facpubs/6 


\section{CRAFTING, COMMUNITY, AND \\ COLLABORATION: \\ Reflections on the Ethnographic Sala Project at the Pukara Lithic Museum, Peru}

\author{
Elizabeth A. Klarich \\ SMITH COLLEGE
}

\begin{abstract}
The Museo Lítico Pukara (Pukara Lithic Museum) is an archaeological site museum in the small highland town of Pucará in the northwestern Lake Titicaca Basin of Peru. Recently, an ethnographic sala (exhibition space) was developed and installed within the museum that focuses on local craft production and its role within the agro-pastoral economy, regional exchange systems, and other household-level and community activities. The sala is the culmination of a decade-long effort by national and foreign archaeologists, anthropologists from the regional university and their students, the Peruvian Ministry of Culture, and the townspeople of Pucará. This article presents a brief history of the museum, describes the development of the sala project, and frames the process and results of this project as they relate to discussions of community, collaboration, and value at the intersections of archaeology and ethnography. [collaborative archaeology, community, archaeological site museums, Latin America, Peru]
\end{abstract}

Walking through the streets of Pucará in the southcentral highlands of Peru (Figure 1), a first-time visitor might notice that the local buildings shimmer as the sunlight reflects off the fragments of green glazed pottery firmly embedded in their adobe walls. Looking more closely, one can spot obsidian flakes, bits of animal bones, and an occasional prehistoric pottery sherd. The history of Pucará and the underlying archaeological site of Pukara (Figure 2) is literally captured in these walls; the adobe bricks are replete with broken modern clay molds, brightly colored Spanish colonial glazewares, local imitations of Inca imperial wares, clunky Collao black-on-red sherds, and intricate Pukara polychromes that have been mined from nearby trash dumps. ${ }^{1}$ These objects have new "lives" as building materials that support the homes, workshops, and other structures in this small town.
The centrally located Museo Lítico Pukara (MLP; Pukara Lithic Museum), an archaeological site museum, is also a daily reminder of the integral role of local prehistory for Pucareños (townspeople), visiting researchers, and tourists (Figure 3). A previous publication by the author and colleagues (Paredes et al. 2006) provides a detailed history of this museum, which was refurbished in the early 2000 s after having fallen into disuse for two decades. The discussion, which was included in the edited volume Archaeological Site Museums in Latin America (Silverman 2006), outlined the renovations to the facility, local involvement in museum-related activities, concerns related to site and object conservation, and the growing influence of tourism on the local economy. Also mentioned briefly were tentative plans to diversify the scope of the MLP through development of a new sala (exhibition space) dedicated to contemporary ceramic production, the primary economic activity in Pucará (Paredes et al. 2006:79).

The present discussion focuses on the development of the ethnographic sala within the archaeological site museum, which is a project that spanned almost a decade from initial conception to installation in early 2011. The organizers of the sala project - the author and fellow archaeologists who codirect the Pukara Archaeological Project-viewed it as an opportunity to involve townspeople, local anthropology colleagues and students, and tourism professionals in activities typically restricted to government museum personnel. The primary goal was to facilitate a collaborative endeavor that would include diverse perspectives from various stakeholder groups during all stages of the process: from the formulation of sala themes to the development of display collections and didactic materials to the installation of the exhibit. The following discussion begins with a brief history of the MLP (see Paredes et al. 2006 for additional details), describes more recent developments related to the ethnographic sala, and concludes by exploring how this project contributes to our understanding of the concepts of community, collaboration, and value at the intersections of archaeology and ethnography.

\section{Background to the Museo Lítico Pukara}

The primary focus of the MLP is the archaeological culture and type site of Pukara, which was the first major population center in the northern Lake 


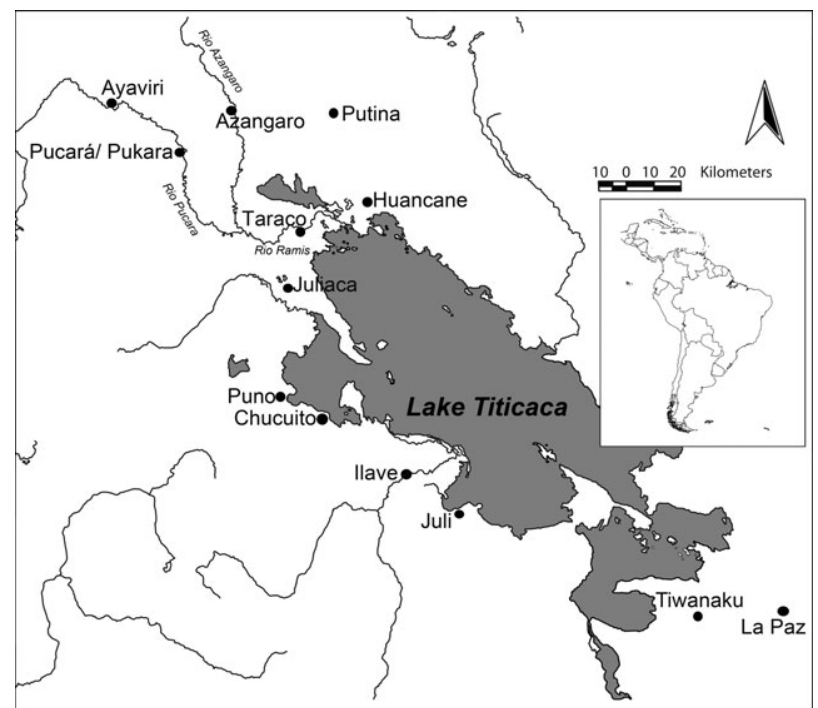

Figure 1. Lake Titicaca Basin map with Pucará/Pukara, modern towns, and other sites mentioned in the text.

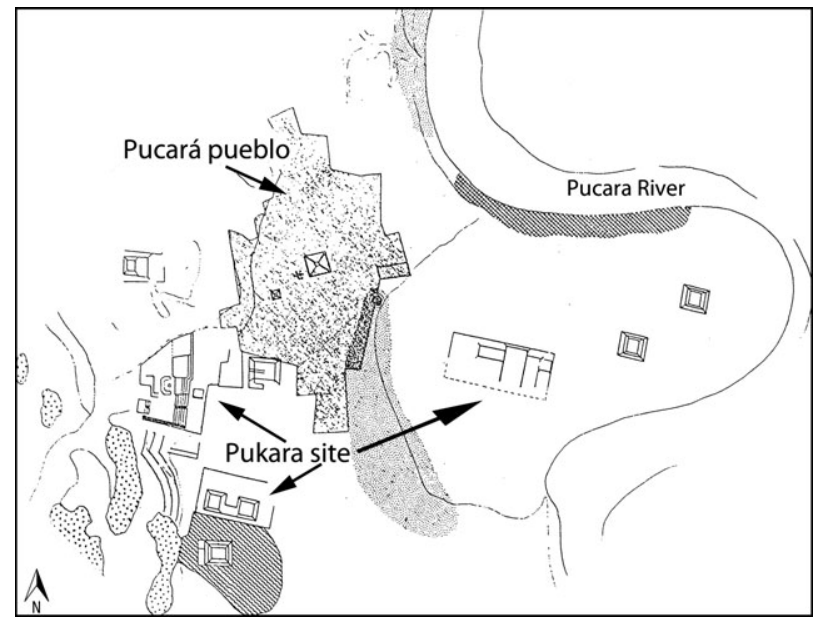

Figure 2. Overview of the town of Pucará and the archaeological site of Pukara (map adapted from Wheeler and Mujica 1981).

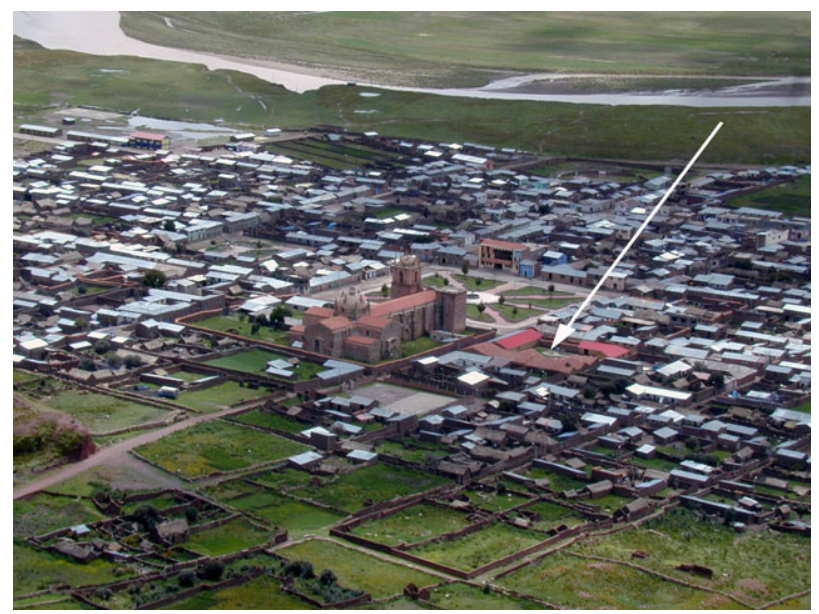

Figure 3. Location of the Museo Lítico Pukara in Pucará. (Photo by Elizabeth A. Klarich, 2002.)

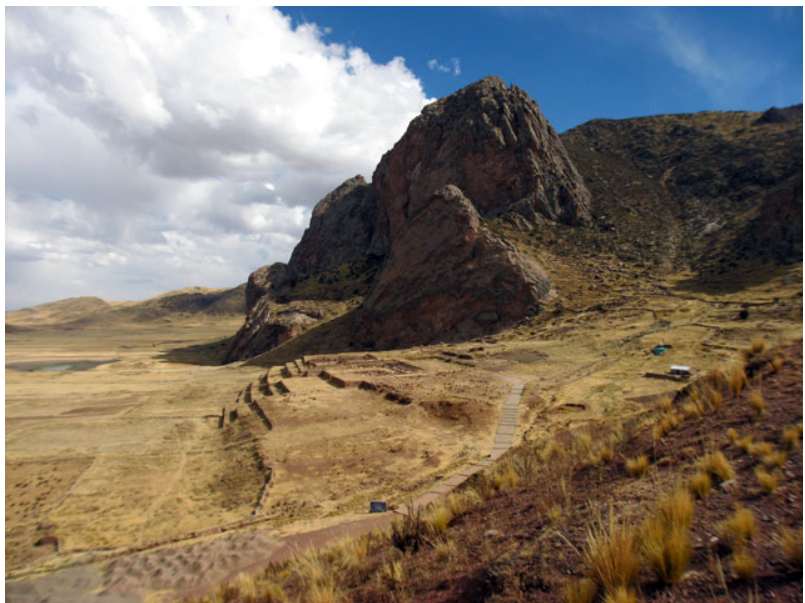

Figure 4. Archaeological site of Pukara. Stone-lined terraces and sunken court structures are known as the Qalasaya complex, and the Peñon is the large sandstone outcrop in the background. (Photo by Matthew Wilhelm, 2006.)

Titicaca Basin approximately 2,000 years ago (Figure 4). The monumental stone-lined platforms and sunken court structures visible today were built and used for several centuries by the Pukara culture. While our knowledge is limited regarding how or why Pukara was abandoned circa C.E. 400, there is ample evidence of subsequent site re-use and modification by the Colla, Inca, and Spanish over the following centuries. ${ }^{2}$ Today, the adjacent town of Pucará is home to approximately two thousand Spanish- and Quechua-speaking residents who practice agro-pastoralism and are recognized throughout the region as pottery specialists. ${ }^{3}$

The MLP is located on the corner of the Plaza de Armas (central square) adjacent to Santa Isabel, an impressive colonial church built during the early 17 th century (Figure 3). The museum building was first constructed in the mid-1970s to provide laboratory space and storage rooms for Plan COPESCO (Special Commission for the Supervision of the Tourist and Cultural Plan of Peru-UNESCO) but fell into disuse in the early 1980s due to political unrest in the region (Paredes et al. 2006). When researchers returned to Pucará in the late 1990s, the salas, storage and lab facilities, and residence were in complete disrepair; however, these have since been renovated with the financial and logistical support of various archaeological projects and the government. Today the museum includes four main salas (Figure 5) and a patio with archaeological materials on display, serves as the regional repository for archaeological collections, and 


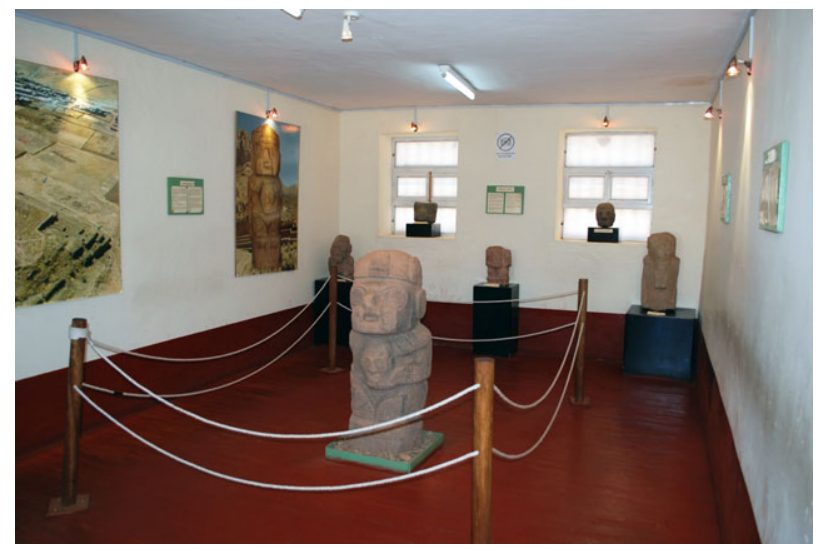

Figure 5. Prehistory sala in the Museo Lítico Pukara. (Photo by Elizabeth A. Klarich, 2009.)

includes a lab space and residential area that houses the museum staff and visiting researchers. On an institutional level, the MLP is one of dozens of site museums operated by the Ministry of Culture, which is administered from Lima and has a regional office in the city of Puno, about two hours south of Pucará. ${ }^{4}$

\section{Recent Developments: The Ethnographic Sala PROJeCt}

It has been over a decade since the author, fellow codirectors of the Pukara Archaeological Project, and the staff of the Ministry of Culture first discussed the possibility of expanding the MLP by developing an ethnographic sala. Although the subject material of the proposed sala did not fit neatly into an archaeological site museum, we conceptualized it as part of a long-term program aimed at expanding the mission and vision of the museum through local engagement and collaboration. As discussed previously (Paredes et al. 2006), many Pucareños view the MLP as a space catering to foreign tourists and as a resource primarily benefitting the Ministry of Culture through the collection of entrance fees. Was it possible to begin to change this perception? Could the various local and nonlocal stakeholders-townspeople, government officials, representatives of the Ministry, and interested professionals in the fields of anthropology, tourism, and development- "come to the table" to conceptualize, develop, and install the new sala? Could the process of working together and the resulting space for new voices contribute to an increased relevance of the MLP within Pucará? Also, might the presence of a new sala attract more visitors, and more revenue, to the town?
The first step of the project required obtaining the permission of the Ministry of Culture to add a new sala. In 2002, the then director of the regional office, Rolando Paredes, agreed to support the project and oversaw the cleanup and renovation of a large room that had been used for collections storage. The next step was to secure funding, which seemed a formidable task because the project did not fit neatly into typical funding categories; it did not involve archaeological field research nor did it focus primarily on curating or conserving a museum collection (Pyburn 2003). Fortunately, the Wenner-Gren Foundation awarded the Pukara Archaeological Project an International Collaborative Research Grant (ICRG), which included \$5,000 for a "training" component designed to complement the archaeological research agenda. The central goal of these trainings, as outlined by Wenner-Gren, is to contribute to the development of the field of anthropology in the host country. ${ }^{5}$ Fortunately, there is quite a bit of flexibility in terms of project design and execution. We proposed to use the training funds to collaborate with Peruvian anthropology colleagues in facilitating a fieldwork practicum for local undergraduate students related to the ethnographic sala, which is discussed in more detail below.

The sala project began in earnest the summer of 2010 during the archaeological field season. Initially, it was unclear how to reach the greatest number of people in Pucará to gauge interest in the project. In the past, we had hosted events at the museum, attended formal and informal gatherings at the mayor's office, and shared information about the archaeological project over the local radio station. After discussing these options with several people, it was suggested that we attend the monthly meeting of the Mesa de Turismo (tourism board), an organization with representatives from the half a dozen asociaciones (guilds) of craftspeople, restaurant owners, tour guides, and interested townspeople. At the meeting, one of the co-directors of the archaeological project gave a brief presentation and then fielded questions. Participants discussed the project goals, the potential contributions of townspeople, possible economic and social benefits, and options for the central theme. Those attending the meeting decided that the sala should focus on contemporary ceramic production, which was not surprising considering that 
80 to 90 percent of Pucareños are part- or full-time potters (Paredes et al. 2006). Approximately twenty families signed up to participate in the interviews, which were to be conducted in household workshops over the next few weeks.

David Oshige, Bárbara Carbajal, and myself (the co-directors of the archaeological project in 2010); Robert Ramos (an anthropology professor from the National University of the Altiplano-Puno, UNAP); and a group of undergraduate students enrolled in Ramos's museology course on cultural patrimony conducted 23 interviews in Pucará (Figure 6). Each meeting lasted approximately an hour and typically included a structured interview followed by a tour of facilities within the potter's house compound. Several of the undergraduates from the UNAP are fluent Quechua speakers, which provided an opportunity for them to lead the interview process and also resulted in more household members participating (many older Pucareños are not conversant in Spanish). While just over half of the potters were comfortable being videotaped, all those interviewed did allow for photographs to be taken of finished products, workshop areas, kilns, storage facilities, and attached shops. We also offered to photograph their families and copies of all images were distributed to the participants.

Local potters produce a variety of utilitarian and decorative ceramics, but they are best known for the toritos de Pucará, which are decorated ceramic bulls placed in pairs on rooftops to promote fertility and prosperity for the household (see endnote 3 ). These

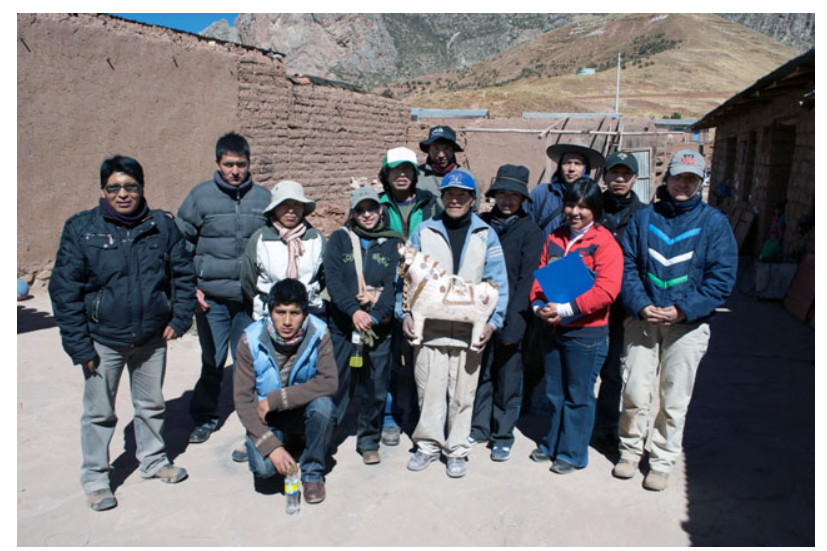

Figure 6. Anthropology and tourism students from the UNAP during an interview with Lizardo Pedro Aguilar (holding torito) in his household workshop. Also present are David Oshige and Bárbara Carbajal, project codirectors. (Photo by Elizabeth A. Klarich, 2010.) bulls were first made in the neighboring community of Checca Pupuja, but they received their moniker because they were sold at the Pucará train station and in shops on the town's major highway as early as the 1940s. Toritos have been transported to rooftops in other highland regions, onto coffee tables in Lima, and into curio cabinets abroad, spreading the fame of Pucará as a center of artesanía (craft production). In spite of the fame of the toritos and the very active tourist industry in Pucará, we found, during the interviews, that most decisions related to pottery production primarily reflect the dynamics of local, regional, and interregional demand. Potters spoke of stockpiling pottery for sale in ferias (annual regional markets) and of balancing craft production with farming and herding. Upon first glance, toritos may be the most visible type of pottery in Pucará, but through the interviews we were able to document a wide variety of vessel types made with unique clay recipes, construction techniques, and firing technologies in family workshops (see Roddick and Klarich 2013).

In addition to the formal interviews with potters, we gathered valuable information for the sala project "accidentally" through informal conversations in town. Pucareños are agropastoralists who raise llamas, alpacas, and sheep for wool that is used to weave, knit, crochet, and make tapestries. We knew there was local textile production-women knit at their tourist stands in the main plaza and spin while out herding animals - but no one at the meeting of the tourism board suggested including these activities in the new sala. It was not until we were chatting with some of the vendors in the plaza that we found out a number of women had recently formed a cooperative dedicated to fiber-based crafting activities. We asked if they might be interested in contributing to the sala project, and within a few days there were a dozen women sitting around at the museum, drinking tea, knitting, and providing detailed accounts of their work. Unlike the potters interviewed-who preferred to speak with us privately in their household workshops - those involved in fiber production met with us as a large group multiple times and appeared to share resources and information widely (Figure 7). They were enthusiastic participants in the interviews, broadening our understanding of contemporary craft production, household organization, and the key role 


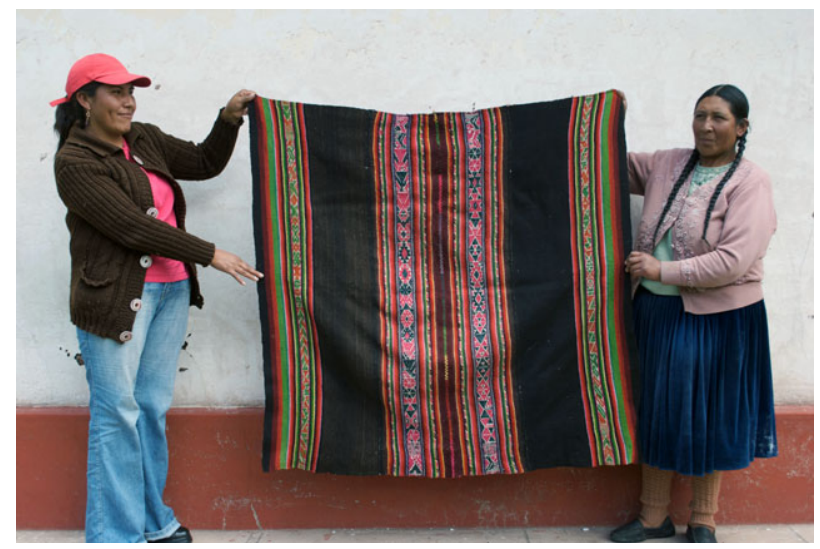

Figure 7. Pucará weavers - Flora Lucila Alemán Limachi and Yolanda Apancho Orccoapaza - with example of finished textile shared during group interview. (Photo by Matthew Wilhelm, 2011.)

of women in interregional exchange and the tourist economy. Their contributions of information, raw materials, finished products, and photographs significantly broadened the scope of the sala project, resulting in a more representative, inclusive space.

Once the transcripts and other documentation had been translated, organized, and synthesized by the interviewers, the project organizers submitted a detailed exhibition proposal to the Ministry of Culture in Puno. Within a few months, the regional director approved the proposal with only a few minor changes. The final stages of the project-developing wall texts, choosing images, collecting donated objects, selecting the display cases and lighting, and installing the exhibit - were completed by the project organizers and Ministry of Culture personnel in late 2010 and early 2011.

The new sala, titled La Herencia Pukara: 3000 Años de Historia y Tradición (The Legacy of Pukara: 3,000 Years of History and Tradition), opened at the MLP in late January 2011 as a permanent exhibit space (Figures 8 and 9). It presents textile and pottery production as ubiquitous, dynamic, and interdependent practices in Pucará households. The cases display raw materials, tools, and finished products donated by local artisans, and they will be updated annually to allow for new materials to be incorporated (Figure 10). Numerous wall texts, including two production sequence diagrams, detail pottery and textile production. Each activity is broken down into stages: raw material procurement, materials preparation, and final production (adapted from Miller 2009). These stages are also illustrated with large-format

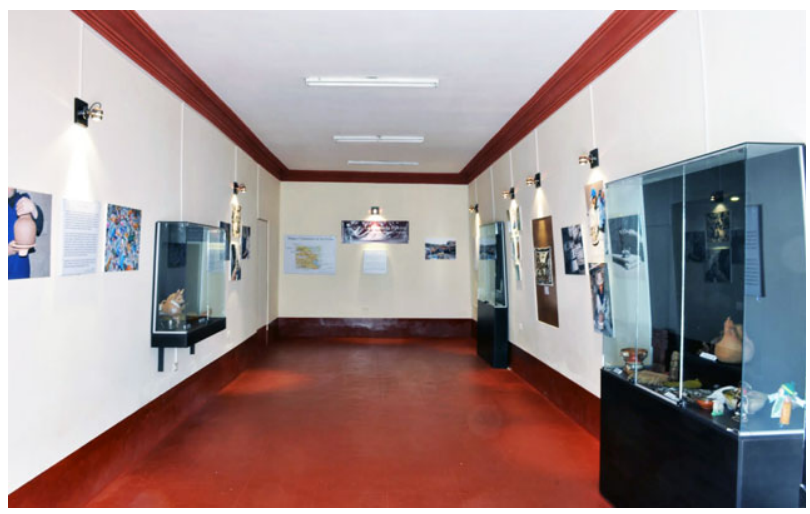

Figure 8. Overview of ethnographic sala. (Photo by Brie Anna Langlie, 2011.)

photos of potters and weavers that were taken during the interviews. A case dedicated to the toritos gives a brief history of their development and mentions their possible links to pre-Hispanic ritual practices. Last, a regional map and calendar of annual markets emphasize the vast trade networks in which Pucará potters and weavers participate (Figure 9). In sum, craft production is presented as a major organizing principle within the annual cycles of the agro-pastoral economy, regional exchange systems, and other household-level and community activities.

\section{Contextualizing the Ethnographic Sala Project}

The following discussion explores two interrelated concepts - community and collaboration-in order to contextualize the sala project within related discussions in the fields of anthropology, archaeology, museum studies, and heritage management.

\section{Community}

Members of our archaeological project had lived and worked in Pucará for several years before applying for the Wenner-Gren ICRG and were familiar with local tensions related to competing land claims, the tourism industry, NGO-sponsored projects, and a number of other issues. However, when we put together the ICRG, we simply referred to the "community of Pucará" as a monolithic stakeholder group in a list that also included the museum staff, tourism professionals, archaeologists, and local anthropology colleagues and students (see Chilton 2010:148 for a similar discussion in North America). We had not defined "community" in the project goals or more generally in the proposal; it was used primarily as a 


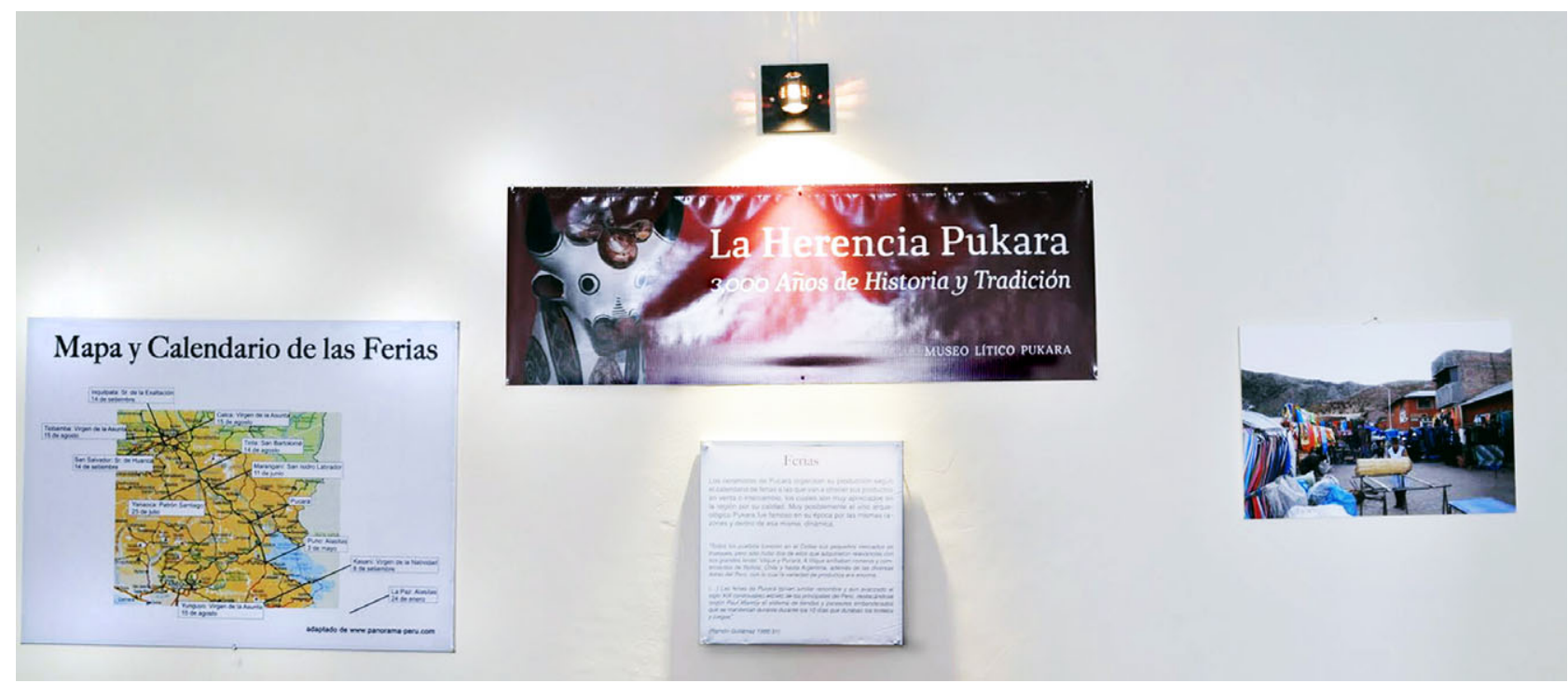

Figure 9. Wall banner for ethnographic sala and map of annual ferias (markets) visited by Pucará potters. (Photo by Brie Anna Langlie, 2011.)

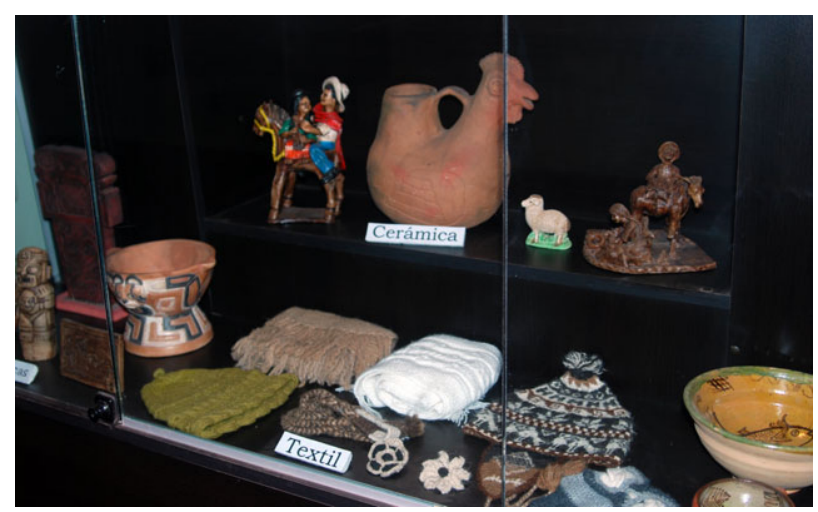

Figure 10. Detail of display case with weavings and pottery produced in Pucará. (Photo by Elizabeth A. Klarich, 2013.)

geographical and cultural term (shared language, history, et cetera) that did not recognize or address the internal heterogeneity within Pucará. What "community" would be represented in the sala?

Such uncritical approaches to "community" have been widely critiqued in the social sciences and, most germane to this discussion, within anthropological archaeology (e.g., Agbe-Davies 2010; Marshall 2002) and heritage studies (e.g., Alivizatou 2012; Waterton and Smith 2010). Specifically, definitions that rely on a "combination of a limited set of characteristics: rural, geographically defined, traditional, working class, ethnic, face to face, and so forth" (Waterton and Smith 2010:10) tend to homogenize the "community" in question, neglecting to leave spaces for internal conflict, power disparities, difference of opinion, and many of the other "messy" elements that are necessary to consider. For example, even within the "community" of Pucará potters, there are different types of producers with a wide range of economic resources, political clout, and cultural capital. The primary division appears to be between full-time, independent potters and part-time, household-level potters. The independent potters - of which there are only a handful - are recognized nationally and often internationally as "artists" who have taken pottery production in a unique direction. They are invited to represent Pucará in competitions, sell their wares directly to galleries in Lima and abroad, and have been featured in documentaries. Their houses further differentiate them from other townspeople: they are multi-story, cement block residences with a façade of colorful tiles and decorative metal bars on the windows. None of these potters were present at the meeting of the tourism board, and based on our experiences and conversations, they are often away from Pucará.

In contrast, the majority of local potters produce at the household level and balance craft production with the seasonal demands of farming and herding. They sell their wares locally and at regional markets, live in modest adobe house compounds that include workshop spaces, and tend to join one of the approximately half dozen guilds in Pucará. Based on our experience at the tourism board meeting and through discussions in town, it was clear that the primary informants for the sala project would be householdlevel craftspeople and not the independent potters 
known widely beyond Pucará. The former had more to gain professionally and perhaps even personallymost expressed their hope that information about local artisans might inspire casual visitors to spend more time in town, tour workshops, and purchase their products. Several also mentioned that they were invested in the continuation of pottery production in Pucará. Teaching the craft to their children ensured that if their children's educational or professional aspirations were not realized (typically meaning outside of Pucará), they would always have practical skills as a "backup" to support themselves. It was these household-level potters plus the cooperative of weavers who actively participated in the interviews, allowed photos of themselves to be displayed, and generously donated their products for the exhibition.

Even with this apparent support, there were some concerns that factionalism among local guilds might derail the sala project or that the interviews might exacerbate existing tensions. Craft guild membership is based on kin relations, political ties, economic relationships, or neighborhood affiliation as the town expands and new residents move to Pucará. According to our observations over the last decade and many conversations with Pucareños, disagreements among guilds have disrupted and halted locally and NGOsponsored efforts at creating community-wide marketplaces and workshops. Would this be the case again if competing narratives emerged during the interview process? Fortunately, we found that potters focused on their household workshops and the contributions of their family members during our discussions. Guild membership and related local politics were occasionally mentioned, but they did not play a major role in any of the interviews. Perhaps the project contributed, in some small way, to at least temporarily shifting the focus from divisive issues among guilds to the commonalities among potters in Pucará.

In retrospect, instead of thinking of the sala as a place that tells the story of the community of Pucará, it seems more fruitful to conceptualize the project as contributing to the creation of community: "Communities [thus] become social creations and experiences that are continuously in motion, rather than fixed entities and descriptions, in flux and constant motion, unstable and uncertain" (Waterton and Smith 2010:9). It was apparent from the first interviews that each craftsperson has an intimate relation- ship to his or her craft-one they have typically practiced since childhood-and recognizes the unique insights they bring to the sala project "community." Questions to potters about clay recipes and temper sources fostered detailed conversations about technology, landscape, trade, economic development, and a myriad of other topics related to the material reality of pots and to the social relationships they often facilitate. The weavers talked about building their herds, tasks related to caring for their animals, the countless hours spent processing wool, and they even touched upon changes in pastoralist strategies resulting from highway construction and an influx of cattle for milk production. In some instances, an interview shifted directions as the interviewees asked the interviewers to explain our research goals and what we were trying to learn about ancient potters and weavers through our excavations at Pukara. How, they asked, did this relate to what we observed in Pucará today? This craft-centric community "coalesce[d] around shared interests, common causes or collective experiences" (Waterton and Smith 2010:9; see also Agbe-Davies 2010:385; Marshall 2002). Pottery production and weaving provided a collective vocabulary and clear focus for the project archaeologists, local craftspeople, anthropology students from the UNAP, and other participants who might otherwise have struggled to find common ground. These encounters created an unanticipated opportunity to explore intersecting interests and diverse perspectives among the various stakeholders. Perhaps the success of the interviews reflects "the universalizing power of our desire for community" (Waterton and Smith 2010:6) and the way that telling stories can reassure people of their community membership (Holtorf 2010:446).

\section{Collaboration}

"Collaboration," like "community," is a concept that merits discussion, particularly as more research projects self-identify as collaborative in some aspect, including our own in Pucará. Fortunately, theorizing "collaboration" has gained serious momentum as archaeologists work more closely with descendant communities and other stakeholders in the formulation of research designs, project execution, and the interpretation of data (e.g., Colwell-Chanthaphonh and Ferguson 2008; La Salle 2010; Silliman and 
Ferguson 2010; see also Aas et al. 2005; Meskell and Sibongile Van Damme 2008 in the heritage field; Schultz 2011 and Scott 2012 in museum anthropology). In fact, Chip Colwell-Chanthaphonh and T. J. Ferguson provide a framework for characterizing such endeavors within archaeological practice:

we see that collaboration in practice exists on a continuum, from merely communicating research to descendant communities to a genuine synergy where the contributions of community members and scholars create a positive result that could not be achieved without joining efforts. [2008:1]

To determine if a project model is on one end of the continuum of practices ("resistance"), on the other end ("collaboration"), or somewhere in between ("participation"), the authors define six features to consider (Table 1; adapted from Colwell-Chanthaphonh and Ferguson 2008:11, Table 1.1)

After revisiting the goals, methods used, and outcomes of the MLP sala project, we were able to reflect on where our efforts fell on this "collaborative continuum." First, the directors of the archaeological project and the Ministry of Culture personnel initiated

\begin{tabular}{|c|c|c|c|}
\hline Features & Resistance & Participation & Collaboration \\
\hline $\begin{array}{l}\text { (1) How goals } \\
\text { develop }\end{array}$ & Opposition & Independently & Jointly \\
\hline $\begin{array}{l}\text { (2) Information } \\
\text { flows among } \\
\text { stakeholders }\end{array}$ & Secreted & Disclosed & Flows freely \\
\hline $\begin{array}{l}\text { (3) Stakeholder } \\
\text { involvement }\end{array}$ & None & Limited & Full \\
\hline $\begin{array}{l}\text { (4) Stakeholder } \\
\text { voice/input }\end{array}$ & None & Some & Full \\
\hline $\begin{array}{l}\text { (5) How } \\
\text { support is } \\
\text { gained among } \\
\text { stakeholders }\end{array}$ & $\mathrm{n} / \mathrm{a}$ & Solicited & Tacit \\
\hline $\begin{array}{l}\text { (6) How } \\
\text { stakeholder } \\
\text { needs are } \\
\text { considered }\end{array}$ & $\mathrm{n} / \mathrm{a}$ & $\begin{array}{l}\text { Needs of most } \\
\text { parties } \\
\text { mostly met }\end{array}$ & $\begin{array}{l}\text { Needs of all } \\
\text { parties met }\end{array}$ \\
\hline
\end{tabular}

Table 1. Evaluating collaborative efforts in the MLP Ethnographic Sala Project (adapted from Colwell-Chanthaphonh and Ferguson 2008:11, Table 1.1). the sala project, and its goals were later fine-tuned through working with the UNAP undergraduates and conducting the interviews. Second, information first flowed "out" from the project organizers and then "back" from the interviewees, with most stakeholder groups communicating to each other through the organizers. Third, stakeholders were heavily involved in some aspects of the project (e.g., data gathering) but not as much in others (e.g., the sala layout). Fourth, stakeholders had some voice (e.g., expanding the sala central theme to include weaving) but did not contribute to the generation of wall texts (in Spanish) and the printed triptychs (in English, Spanish, and Quechua). These were formulated by the project organizers based on interview data and on written feedback from the UNAP students. Fifth, the project organizers solicited support for the sala project from the various groups who we had identified as "stakeholders." Finally, it remains unclear if the needs of all parties or stakeholders were met; this is discussed in more detail below.

In sum, the MLP sala project fits neatly into the category of "participation" as defined by ColwellChanthaphonh and Ferguson (2008) rather than full "collaboration," as intended within the training component of the ICRG proposal. What could we have done differently? First, we should have avoided a "top-down mode" of information flow in which "the archaeologist is the convener and decision-maker who mediates among stakeholders throughout the project" (Hart 2011:28; see also Alivizatou 2012; Smith 2006). As outlined by Siobhan Hart (2011) in her discussion of polycommunal archaeology, this mode does not redistribute power because archaeologists remain the authorities, and it also hampers communication and compromise among stakeholder groups. This form of organization partially reflects the constraints of situating the sala within a government-run museum instead of a separate community museum (e.g., Camarena and Morales 2006; Hastorf 2006); however, surely there could have been more opportunities for stakeholders to interact directly during the project and to redirect information flow.

Second, stakeholder voices should have been heard consistently through every step of the process. This is of particular importance when dealing with intangible heritage like crafting traditions, which is unfamiliar territory for most archaeologists: 
With intangible cultural heritage, the traditions exist outside the museum, in the community. They reside under the authority of the people who practice them. People, unlike objects, do talk back. They do complain about how they are placed and how they and their traditions are treated and mistreated.... In order to deal with intangible cultural heritage, museums must have an extensive, fully engaged, substantive dialogue and partnership with the people who hold the heritage. Such partnership entails shared authority for defining traditions, and shared curation for their representation. [Kurin 2004:7]

The issue of "shared authority" is key to this discussion; there were several important decisions made during the development and installation stages that should have been more inclusive. For example, the project organizers, the Ministry of Culture staff, and student volunteers from the UNAP developed the text, selected the images, decided on object placement, and installed the sala. Ideally, all interested stakeholders, especially local craftspeople, would have participated in every stage of sala development. Unfortunately, time limitations, budgetary considerations, and bureaucratic issues provided a number of challenges during the final stages of the project, which we were determined to complete for the sala to open in early 2011. Fortunately, we have learned a great deal through this project, and the ethnographic sala is only one stage in a long-term commitment to collaboration in Pucará.

\section{Reflecting on the Sala Project}

Collaborative projects can be socially messy, highly political, and resource-intensive endeavors with unique sets of challenges (Nicholas et al. 2008). For example, we first struggled with how to shift from conceptualizing the MLP as a repository for the tangible (e.g., pottery, stone tools, and so on from archaeological projects) to a place where intangible cultural heritage (e.g., information about crafting practices, traditions, and so on from our interviews) is presented, preserved, protected, and shared with various publics (Kurin 2004). Did this newly expanded version of the MLP "work"? Second, the project organizers - all trained as archaeologists_-were operating outside their areas of expertise to gather, interpret, and present the interview data in the sala. What type of "archaeology" were we doing, if any? Should we have been the ones directing this project? Lastly, the sala has been completed and is open to the public. What was actually accomplished through this project and who benefits?

\section{What Is the New Museo Lítico Pukara?}

Before the installation of the ethnographic sala, the MLP fit neatly into the definition of an archaeological site museum: "[a] building located at an archaeological site in which exemplary excavated materials from the site, and perhaps from related sites, are displayed, accompanied by explanatory texts that interpret the site and its archaeological culture for the public" (Silverman 2006:4). However, the MLP became a different, and not clearly defined, type of museum as contemporary objects and their stories were introduced through the new sala. Joint prehistory and ethnography museums exist around the world, but they generally are conceptualized as such from their inception. In the case of the MLP, the breadth of the content has been expanded in significant ways, but without any clear signals such as a name change or a new, cohesive narrative. This "tacking on" of the new sala is far from ideal for many reasons; however, the most pressing concern is that visitors conclude that the lives of contemporary Pucareños are presented as convenient analogues for interpreting the ancient objects in the rest of the MLP.

Concerns about representation and interpretation are based on the fact that most tourists know very little about the region and likely will not spend enough time at the MLP to think critically about the complex relationships between the past and present. It was also clear from observations made by a project member documenting museum visits (Coffey n.d.) that the guides leading daily tours at the MLP bombard the visitors with inaccurate information, a problem that may be exacerbated as they add the ethnographic sala into their circuit. For example, a guide explained to a group of approximately eighty tourists that "the ancient city of Pukara had a factory for toritos and the production of these little animals had been the main economy of Peru" (Coffey n.d.). While the presence of Eurasian livestock 2,000 years ago in the Americas may seem like an obvious error, it is com- 
mon for untrained, nonlocal guides to conflate the deep past, colonial era, and recent history in their narratives. Our primary concern was that visitors would leave the museum with a sense that they had visited a place and "met" people relatively untouched by the passage of time.

Issues of "timelessness" are not unique to the MLP; it is a common practice within the Peruvian tourism industry to present visitors with a narrative of cultural continuity that espouses fabricated links across the miles and over millennia. For example, "in Cusco, an essentialized and homogenized past is co-opted into the service of creating an authentic tourist experience. Agents of tourism wantonly conflate time, place, and culture" (Silverman 2002:887). Research in the Mundo Maya (Maya World) also provides a useful analogue outside of the Andes:

One aspect of marketing tourism in the Mundo Maya has been to stress the millenarian nature of Maya culture characterized by cultural continuity between contemporary Maya speakers and the prehispanic population. ... The Mundo Maya, however, markets the Maya through unreconstructed essentialism, glossing over the discontinuities between contemporary and prehispanic Maya people. [Magnoni et al. 2007:365]

Similarly, existing data do not support cultural or linguistic continuity between the people who built ancient Pukara and contemporary Pucareños. Archaeologists and historians continue to explore and document initial settlement, site expansion, periods of abandonment and re-occupation, and population relocation throughout the site's long and complex history.

While it was not an option to rework the overall narrative of the MLP, it was possible within the sala to present examples of both cultural continuity and change by focusing on crafting practices. For example, some components of local craft production do have considerable time depth, such as the exploitation of local clays and pigments, production at the household level, and participation in vast regional exchange networks. There have also been significant changes in the organization of crafting practices over the last few decades due to new technology such as electric kilns. Ideally, visitors will leave the MLP with a richer understanding of the dynamism of craft production and other activities central to the lives of Pucareños today without assuming cultural continuity across the millennia.

\section{Ethnoarchaeology?}

Like many other archaeologists, in Pucará we moved outside the comfort zone of our formal academic training in an attempt to develop a collaborative, community-based project (e.g., Ardren 2002; Castañeda and Matthews 2008; Colwell-Chanthaphonh and Ferguson 2008; Derry and Malloy 2003; Hart 2011; Heckenberger 2008; Little and Shackel 2007; Marshall 2002; Nielson et al. 2003; Silliman 2008). Typically these projects integrate ethnographic and archaeological approaches with a variety of goals: to develop research questions relevant to stakeholders groups; to reconsider aspects of archaeological theory and practice; and, more concretely, "to deepen indigenous or other local histories, revitalize neighborhoods, solidify land claims, repatriate cultural objects, or legitimate authority" (Hollowell and Mortensen 2009:4-5). There are a number of labels for these approaches - for example, archaeological ethnography (Hamilakis 2011; Meskell 2005), ethnographic archaeologies (Castañeda and Matthews 2008), ethnocritical archaeology (Zimmerman 2008), and ethnography in archaeology (Hollowell and Mortensen 2009), among others - and they range from short-term outreach programs to long-term projects that often integrate archaeological research, educational programs, heritage management, and sustainable economic development.

When the sala project began over a decade ago, there were considerably fewer published case studies or reflections on comparable projects, which meant that we improvised extensively, particularly in the earlier stages. In retrospect, however, the goals of the sala are most consistent with the "interconnected facets" of archaeological ethnography such as reflexivity, political commitment, multitemporal approaches, and dedication to "transcend[ing] the boundaries between the researcher and his or her diverse publics" (Hamilakis and Anagnostopoulos 2009:65). While these "facets" provide a useful framework, it was through reviewing case studies that key parallels with our efforts became apparent. For example, Yannis Hamilakis (2011) discusses how during his archaeo- 
logical ethnography project on Poros, Greece, they navigated various political, economic, and social tensions surrounding the site of Kalaureia. Similarly, we found nearly every discussion about Pukara and the MLP infused with tensions resulting from property disputes, local distrust of the Ministry of Culture, and competing interests related to tourism and development. In fact, our attempts to understand the sources of these tensions motivated the early phases of the ethnographic sala project (see Paredes et al. 2006). Looking forward, Hamilakis's work at Kalaureia details a number of exciting strategies to consider incorporating into our long-term research program. Their three-year project involved archaeologists, anthropologists, photo bloggers, and photo ethnographers documenting a "series of parallel and often conflicting discourses about the site" (Hamilakis 2011:407). It is the variety of discourses about Pukara that we next seek to explore with an expanded team of scholars trained outside the field of archaeology.

\section{Who Benefits?}

It can be difficult to gauge the success of collaborative projects beyond their good intentions (La Salle 2010). However, if the sala project is to provide insights for future projects in Pucará or contribute to the growing field of collaborative archaeological research, it is necessary to attempt some measure of "value" for the various stakeholders. While it is too early to determine the long-term impacts of the sala, there are short-term benefits that can be briefly outlined by borrowing a framework from cultural resource management. In this framework- developed by the think tank Demos for the Heritage Lottery Fund (HLF) in the United Kingdom - three kinds of "public value" were identified that could be created by heritage organizations: "the conservation of things that are significant to people ('intrinsic values'); the economic, social and environmental benefits created through policy or investment in heritage ('instrumental benefits'); and the values demonstrated by heritage bodies themselves ('institutional values')" (Clark 2010:94). The category of "intrinsic value" is further defined to include knowledge value (what a place teaches us about ourselves and society), identity value (how we think of ourselves because of a place), bequest value (ideas of stewardship for future generations), and distinctiveness value (what makes a place special). "Instrumental benefits" include economic development, local benefits such as an improved reputation, benefits to community-wide sentiment or increased understanding, and individual benefits such as skills training (Clark 2010:95). While this particular framework was developed in relation to tangible heritage and is therefore site-centric "intrinsic values" and "instrumental benefits" can also be applied to thinking about the intangible heritage of crafting practices (and their tangible products) featured in the ethnographic sala.

In the short term, the project had "intrinsic value" and provided "instrumental benefits" for the UNAP students and the project organizers. For example, the students gained valuable research experience in a fully funded project, had opportunities to work outside the classroom with their professor and our archaeological team, and learned valuable information about craft production and other intangible heritage. In addition, several of the students utilized their fluency in Quechua to lead the interviews in Pucará, which also served to reinforce the value of this frequently marginalized language. For the project organizers, the value and benefits were wide ranging. We learned new information about contemporary crafting and its possible parallels with prehistoric practices; had the opportunity to rethink the long-term goals of the $\mathrm{Pu}$ kara Archaeological Project, including through this publication; and made myriad personal and professional connections in Pucará, at the UNAP, and the Ministry of Culture through the many years and phases of the sala project.

However, more elusive is whether Pucareños find value in the sala and feel that they have adequately benefitted from their contributions of time, knowledge, and donated objects. Will the sala, located within a government museum, ever feel like a community resource, or will long-standing tensions related to issues of power, control, and access continue to alienate Pucareños from this space? Will the new sala appeal to tourists interested in craft production and result in more purchases of local pottery and weavings? Will these tourists spend more time in Pucará and as a result spend more money on food, lodging, and other goods? On the flip side, might this project have caused harm, perhaps through exacerbating factionalism among craft guilds or by the unintentional exclusion of stakeholders? Finally, changes in government officials, 
museum personnel, lack of long-term funding or guaranteed institutional support, and a number of other factors could quickly derail this seemingly successful project.

\section{Future DiRections}

As mentioned above, the ethnographic sala project is the initial stage in our efforts at archaeological ethnography in Pucará, and future plans encompass two major goals: to determine the successful (and not so successful) elements of the ethnographic sala project and to further integrate ethnographic perspectives into the archaeological project. First, we will invite a cultural anthropologist to conduct follow-up interviews with community members, the staff at the museum, tour guides, and students from the UNAP course to document their reflections on the process. Does their feedback resonate with some of these initial reflections about the successes and shortfalls of the project? What unique perspectives and critiques might they contribute? Second, in terms of future ethnographic research, one option is to explore the role of Pukara within the daily lives of Pucareños, which could also provide interesting comparisons with projects in other regions. This has been a topic of casual conversation for years in Pucará; community members frequently mention Pukara during discussions of local politics, conflicts over economic resources, and contemporary ritual practice. Beyond our research interests in Pukara, long-term cultural resource management plans need to integrate local concerns in light of recent acts of vandalism of several stone slabs at the site-reportedly related to conflict between $\mathrm{Pu}$ careños and the Ministry of Culture over land rights. We look forward to future archaeological and ethnographic collaborations with the variety of stakeholders for whom Pukara is a component of their livelihood, a material connection to the ancestors, a focus of research, or a travel destination.

\section{ACKNOWLEDGMENTS}

The ethnographic sala project at the MLP received extensive logistical support from the Peruvian Ministry of Culture-Puno and the financial support of the WennerGren Foundation (International Collaborative Research Grant, 2008-10), Smith College, and the Mellon Foundation (Five College Mellon Faculty-Student Research Seminar, Summer 2012). We also relied heavily on resources provided by Charles Stanish, Mark Aldenderfer, and Cecilia Chávez of the Programa Collasuyu. The formulation of the ethnographic sala project and its execution would not have been possible without the efforts and innovative contributions of the co-directors of the Pukara Archaeological Project: Bárbara Carbajal Salazar, David Oshige Adams, and Luis Ángel Flores Blanco. Flores was instrumental in the formulation of the original proposal to Wenner-Gren, and Carbajal and Oshige worked tirelessly to finalize the proposal to the Ministry of Culture, develop interview questions, work with students from the UNA-Puno, meet with community members, process data, and finish installation of the sala in early 2011. The sala would not be open without their dedicated efforts. Also, Rolando Paredes and Graciela Fattorini have been loyal supporters of the MLP since it re-opened in the late 1990s.

Many thanks to friends and colleagues for their contributions: Sarah Abraham; Lucio Avila Jimmy Bouroncle; Michael Coffey; Edmundo de la Vega; Eric Gardner; Consuelo Giraldo and Edgar De la Jara; Martha Giraldo; BrieAnna Langlie; Gary Mariscal; Ana Pino; Roberto Ramos and his students from the UNAP, especially Yeny Zarate and Veronica Hancco; and the museum personnel at the MLP. Of course, this project would not have been possible without the generosity of the townspeople of Pucará, including the craftspeople who contributed interviews and objects to the sala, the Mesa de Turismo, and the Apancho and Ttacca families. I also appreciate the contributions of colleagues as this article developed, including Jane Anderson, Traci Ardren, Whitney BattleBaptiste, Elizabeth Chilton, Dana Leibsohn, Maxine Oland, Joel Zovar, and the Anthropology Department at Smith College. Their feedback, in addition to the very constructive criticism received through the peer-review process, helped me to rework the final version into a more self-reflexive article that I hope provides some food for thought in the ever-expanding field of collaborative archaeology. In closing, many thanks to Matt Wilhelm for spending his winter vacation as project photographer and supporting the sala project to its completion.

\section{NOTES}

1. Pukara ("fortress" in the indigenous languages of Quechua and Aymara) is the spelling used to refer to the archaeological site and ancient culture. The modern town is spelled $\mathrm{Pu}$ cará.

2. For more information about the archaeological site of Pukara, see Klarich and Román Bustinza 2012; Stanish 2003.

3. For information on contemporary pottery production, see Litto 1976; Mauldin 2011; Roddick and Klarich 2013; Ruiz Durand 2010. 
4. Since 1971, the National Institute of Culture (INC) managed all issues related to Peruvian cultural patrimony, including archaeological projects and government museums. In 2010, former president Alan Garcia created the Ministry of Culture to integrate a number of existing cultural institutions, including the INC. Therefore, the early stages of the sala project were developed under the auspices of the INC, but it was completed while working with the ministry. To avoid confusion, Ministry of Culture is used throughout for the national agency responsible for cultural patrimony.

5. Information on the Wenner-Gren International Collaborative Research Grant can be found at http://www.wennergren. org/programs/international-collaborative-research-grants, accessed January 15, 2012.

\section{References Cited}

Aas, Christina, Adele Ladkin, and John Fletcher

2005 Stakeholder Collaboration and Heritage Management. Annals of Tourism Research 31(1):28-48.

Agbe-Davies, Anna S.

2010 Concepts of Community in Pursuit of an Inclusive Archaeology. The International Journal of Heritage Studies 16(6):373-389.

Alivizatou, Marilena

2012 Intangible Heritage and the Museum: New Perspectives on Cultural Preservation. Walnut Creek: Left Coast Press.

Ardren, Traci

2002 Conversations about the Production of Archaeological Knowledge and Community Museums at Chunchucmil and Kochol, Yucatan, Mexico. World Archeology 34(2):379-400.

Camarena, Cuauhtémoc, and Teresa Morales

2006 Community Museums and Global Connections: The Union of Community Museums of Oaxaca. In Museum Frictions: Public Cultures/ Global Transformations. Ivan Karp, Corinne Kratz, Lynn Szwaja, and Tomás Ybarra-Frausto, eds. Pp. 322-344. Durham: Duke University Press.

Castañeda, Quetzil E., and Christopher N. Matthews, eds.

2008 Ethnographic Archaeologies: Reflections on Stakeholders and Archaeological Practices. Lanham: AltaMira Press.

Chilton, Elizabeth

2010 Teaching Heritage Values through Field Schools: Case Studies from New England. In Heritage Values in Contemporary Society.
George Smith, Phyllis Mauch Messenger, and Hilary Soderland, eds. Pp. 147-158. Walnut Creek: Left Coast Press.

Clark, Kate

2010 Values in Cultural Resource Management. In Heritage Values in Contemporary Society. George Smith, Phyllis Mauch Messenger, and Hilary Soderland, eds. Pp. 89-100. Walnut Creek: Left Coast Press.

Coffey, Michael

N.d. Observations from the Pukara Lithic Museum (Summer 2010). Unpublished manuscript, Pukara Archaeological Project.

Colwell-Chanthaphonh, Chip, and T. J. Ferguson

2008 Introduction: The Collaborative Continuum. In Collaboration in Archaeological Practice: Engaging Descendant Communities. Chip Colwell-Chanthaphonh and T. J. Ferguson, eds. Pp. 1-32. Lanham: AltaMira Press.

Derry, Linda, and Maureen Malloy, eds.

2003 Archaeologists and Local Communities: Partners in Exploring the Past. Washington, DC: Society for American Archaeology.

Hamilakis, Yannis

2011 Archaeological Ethnography: A Multitemporal Meeting Ground for Archaeology and Anthropology. Annual Review of Anthropology 40:399-414.

Hamilakis, Yannis, and Aris Anagnostopoulos

2009 What Is Archaeological Ethnography? Public Archaeology 8(2-3):65-87.

Hart, Siobhan

2011 Heritage, Neighborhoods and Cosmopolitan Sensibilities: Poly-Communal Archaeology in Deerfield, Massachusetts. Present Pasts 3(1):26-34.

Hastorf, Christine

2006 Building the Community Museum at Chiripa, Bolivia. In Archaeological Site Museums in Latin America. Helaine Silverman, ed. Pp. 8598. Gainesville: University of Florida Press.

Heckenberger, Michael J.

2008 Entering the Agora: Archaeology, Conservation and Indigenous Peoples in the Amazon. In Collaboration in Archaeological Practice: Engaging Descendant Communities. Chip Colwell-Chanthaphonh and T. J. Ferguson, eds. Pp. 243-272. Lanham: AltaMira Press.

Hollowell, Julie, and Lena Mortensen

2009 Introduction: Ethnographies and Archaeologies. In Ethnographies and Archaeologies: 
Iterations of the Past. Lena Mortensen and Julie Hollowell, eds. Pp. 1-17. Gainesville: University Press of Florida.

Holtorf, Cornelius

2010 Heritage Values in Contemporary Popular Culture. In Heritage Values in Contemporary Society. George Smith, Phyllis Mauch Messenger, and Hilary Soderland, eds. Pp. 43-54. Walnut Creek: Left Coast Press.

Klarich, Elizabeth A., and Nancy Román Bustinza

2012 Scale and Diversity at Late Formative Period Pukara. In Advances in Titicaca Basin Archaeology-III. Alexei Vranich, Charles Stanish, and Elizabeth Klarich, eds. Pp. 105-120. Ann Arbor: University of Michigan.

Kurin, Richard

2004 Museums and Intangible Heritage: Culture Dead or Alive? ICOM News 4:7-9.

La Salle, Marina J.

2010 Community Collaboration and Other Good Intentions. Archaeologies 6(3):401-422.

Little, Barbara J., and Paul A. Shackel, eds.

2007 Archaeology as a Tool of Civic Engagement. Lanham: AltaMira Press.

Litto, Gertrude

1976 South American Folk Pottery. New York: Watson-Guptill Publications.

Magnoni, Aline, Traci Ardren, and Scott R. Hutson

2007 Tourism in the Mundo Maya: Inventions and (Mis)representations of Maya Identities and Heritage. Archaeologies 3(2):353-383.

Marshall, Yvonne

2002 What Is Community Archaeology? World Archaeology 34(2):211-219.

Mauldin, Barbara

2011 Folk Art of the Andes. Santa Fe: Museum of New Mexico Press.

Meskell, Lynn

2005 Archaeological Ethnography: Conversations around Kruger National Park. Archaeologies $1(1): 81-100$.

Meskell, Lynn, and Lynette Sibongile Van Damme

2008 Heritage Ethics and Descendant Communities. In Collaboration in Archaeological Practice: Engaging Descendant Communities. Chip Colwell-Chanthaphonh and T. J. Ferguson, eds. Pp. 131-150. Lanham: AltaMira Press.

Miller, Heather Margaret-Louise

2009 Archaeological Approaches to Technology. Walnut Creek: Left Coast Press.
Nicholas, George P., John R. Welch, and Eldon C. Yellowhorn

2008 Collaborative Encounters. In Collaboration in Archaeological Practice: Engaging Descendant Communities. Chip Colwell-Chanthaphonh and T. J. Ferguson, eds. Pp. 273-298. Lanham: Altamira Press.

Nielson, Axel, Justino Calcina, and Bernardino Quispe

2003 Archaeology, Tourism, and Indigenous Communities: An Experience from Nor Lípez (Potosí, Bolivia). Chungará 35(2):369377.

Paredes, G. Rolando, Graciela Fattorini, and Elizabeth A. Klarich

2006 The Tourist Circuit Project at Pukara, Peru: Perspectives from a Local Site Museum. In Archaeological Site Museums in Latin America. Helaine Silverman, ed. Pp. 72-84. Gainesville: University of Florida Press.

Pyburn, K. Anne

2003 Archaeology for a New Millennium: The Rules of Engagement. In Archaeologists and Local Communities: Partners in Exploring the Past. Linda Derry and Maureen Malloy, eds. Pp. 167-184. Washington, DC: Society for American Archaeology.

Roddick, Andrew, and Elizabeth A. Klarich

2013 Arcillas and Alfareros: Clay and Temper Mining Practices in the Lake Titicaca Basin. In Mining and Quarrying in the Ancient Andes: Sociopolitical, Economic, and Symbolic Dimensions. Nicholas Tripcevich and Kevin J. Vaughn, eds. Pp. 99-122. New York: Springer.

Ruiz Durand, Jesús, ed.

2010 Toro, torito de Pucará: Galería y estudios [Toro, torito of Pucará: Gallery and Studies]. Lima, Peru: MINCETUR.

Schultz, Lainie

2011 Collaborative Museology and the Visitor. Museum Anthropology 34(1):1-12.

Scott, Mary Katherine

2012 Engaging with Pasts in the Present: Curators, Communities, and Exhibition Practice. Museum Anthropology 35(1):1-9.

Silliman, Stephen W., ed.

2008 Collaborating at the Trowel's Edge: Teaching and Learning in Indigenous Archaeology. Tucson: University of Arizona Press.

Silliman, Stephen W., and T. J. Ferguson

2010 Consultation and Collaboration with Descendant Communities. In Voices in American 
Archaeology: 75th Anniversary Volume of the Society for American Archaeology. Wendy Ashmore, Dorothy Lippert, and Barbara J. Mills, eds. Pp. 48-72. Washington, DC: Society for American Archaeology.

Silverman, Helaine

2002 Touring Ancient Times: The Present and Presented Past in Contemporary Peru. American Anthropologist 104(3):881-902.

Silverman, Helaine, ed.

2006 Archaeological Site Museums in Latin America. Gainesville: University Press of Florida.

Smith, Laurajane, ed.

2006 Uses of Heritage. New York: Routledge.

Stanish, Charles

2003 Ancient Titicaca: The Evolution of Complex Society in Southern Peru and Northern Bolivia. Berkeley: University of California Press.
Waterton, Emma, and Laurajane Smith

2010 The Recognition and Misrecognition of Community Heritage. International Journal of Heritage Studies 16(1-2):4-15.

Wheeler, Jane, and Elías Mujica

1981 Prehistoric Pastoralism in the Lake Titicaca Basin, Peru, 1979-1980 Field Season. Final Report. Washington, DC: National Science Foundation.

Zimmerman, Larry J.

2008 Real People or Reconstructed People? Ethnocritical Archaeology, Ethnography, and Community Building. In Ethnographic Archaeologies: Reflections on Stakeholders and Archaeological Practices. Quetzil Castañeda and Christopher Matthews, eds. Pp. 183-204. Lanham: AltaMira Press. 